\title{
テラヘルツ波センシング・イメージング技術と応用
}

\author{
大 谷 知 行 $\mathrm{a,b}$ \\ a (国研) 理化学研究所 光量子工学研究センター ( 980-0845 宮城県仙台市青葉区荒巻字青葉 519-1399) \\ ${ }^{b}$ 東北大学大学院理学研究科 物理学専攻 ( T 980-8578 宮城県仙台市青葉区荒巻字青葉 6-3)
}

\section{Sensing and Imaging Technology and Applications of Terahertz wave}

\section{Chiko OTANI a,b}

${ }^{a}$ RIKEN Center for Advanced Photonics, RIKEN (519-1399 Aramaki-Aoba, Aoba-ku, Sendai-shi, Miyagi 980-0845)

${ }^{\mathrm{b}}$ Department of Physics, Graduate School of Science, Tohoku University (6-3 Aramaki-Aoba, Aoba-ku, Sendai-shi, Miyagi 980-8578)

Keywords : Terahertz wave, Millimeter wave, Sensing, Imaging, Beyond 5G/6G

\section{1. はじめに}

100 ギガヘルツ $(\mathrm{GHz})-10$ テラヘルツ $(\mathrm{THz})$ の周波数領域 の電磁波は, テラヘルツ波またはテラヘルツ光と呼ばれ, 電 波と光の境界領域に位置する。1 THz は, $1,000 \mathrm{GHz}\left(10^{12} \mathrm{~Hz}\right)$ であり，波数では $33 \mathrm{~cm}^{-1}$, 波長では $300 \mu \mathrm{m}$ に相当する。 この帯域は，低周波領域はミリ波 $(30-300 \mathrm{GHz})$, 高周波領 域はサブミリ波 $(300 \mathrm{GHz}-3 \mathrm{THz})$ や遠赤外線とオーバー ラップしており, 古くから様々な基礎研究や利用可能性の開 拓が進められてきている。加えて, この帯域の広いバンド幅 の超高速無線通信利用(いわゆる「Beyond $5 \mathrm{G} / 6 \mathrm{G} 」$, 以下, $\mathrm{B} 5 \mathrm{G} / 6 \mathrm{G}$ と略す)に向けた環境整備, 技術開発, そして, 政 府機関の予算投資が盛んに行われている ${ }^{1) \sim 5)}$ 。具体的には, 2030 年頃から $300 \mathrm{GHz}$ 付近の周波数の実利用が開始される という共通認識が世界的に共有されている。

この動きは非常に重要であるため, もう少し掘り下げて述 べておく。通常，新技術の利用は，シーズとニーズ，そして， コストと利益とが折り合って初めて広がるため, 本当に社会 で広く活用されるかどうか自明ではない。実際, 筆者も様々 な場所で,「本当に $\mathrm{B} 5 \mathrm{G} / 6 \mathrm{G}$ は使われるのか？(使われないで 終わるんじゃないか? )」と尋ねられる。5Gの普及もままな らぬ状態で，5G 超の技術が広がるか疑問ではないか，と。 しかし，この推測は当てはまらないと考えるべきである。無 線通信では, 国際電気通信連合・無線通信部門 (ITU-R)が主催 する世界無線通信会議(World Radiocommunication Conference, WRC) で何年も前からロードマップが敷かれ, 各国政府・企 業. 研究機関等を巻き込んで世界共通規格や周波数割当の準

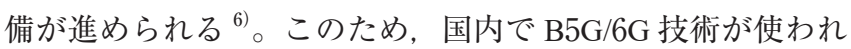
ようが使われまいが，世界は着々と前へ進んでいく。やらな ければ取り残されるだけである。 すべき点である。また， $5 \mathrm{G}$ 関連特許件数は中国がダントッ に多かったため ${ }^{7)}, \mathrm{B} 5 \mathrm{G} / 6 \mathrm{G}$ では, このような後追いの状況 を繰り返さないぞ, という強い危機意識も根底にある。各国
の競争は今後ますます熾烈になると見られる。

2 つめの重要ポイントは, $85 \mathrm{G} / 6 \mathrm{G}$ の潮流が単一技術の進 展として捉えられているのではなく, コロナ後の社会構造の 変革とも密接に関わっているという視点である。実際, NTT docomo や NICT のホワイトペーパーでは, 社会課題の解決 や新しい働き方などを実現する重要なツールの一つとして B5G/6G 技術が組み込まれており ${ }^{1), 5)}$ ，社会全体の変容を見 据えて技術を捉えることも重要である。なお, 筆者の個人的 な意見であるが，この無線通信技術の活用シーンのいくつか は，2015 年にアメリカ DARPA が公表した戦場における通信 技術の使われ方を商用化・実社会化したものとも見なせる ${ }^{8)}$ 。 こちらの資料もぜひ併せて参照して頂きたい。

もうひとつさらに重要なポイントは, 無線通信で使われる 末端の端末通信デバイスは間違いなく半導体となるという点 で, 2030 年·300 GHz に向けデバイスが劇的に小さく安くなっ ていくと捉えておくべきだろう。実際, 研究レベルではすで に数 $\mathrm{mm}$ 角程度の CMOS 送受信機が実現しており, 携帯端末 に搭載できるだけのデバイスが実証されている ${ }^{9)}$ 。後述する センシング・イメージング応用においてもこれまでネックで あったコストの問題を解決できる環境が整いつつある。

\section{2. テラヘルツ波の基本的な性質}

テラヘルツ波は液体の水に強く吸収されるほか, 大気中の 水蒸気にもいくらか吸収される。このため, 無線通信やセン シングで大気中を伝搬させる時にもある程度影響を受けるた め，まずその性質を見ておく。図 1 にテラヘルツ帯の大気に よる減衰率を示す ${ }^{10)}$ 。縦軸が $\mathrm{dB} / \mathrm{km}$ で表されていることに 注意されたい。これは, 大気中を $1 \mathrm{~km}$ 進んだ時に何 $\mathrm{dB}$ 減 衰するかを示しており，200-300 GHz 帯に減衰の少ない領 域が存在することがわかる。この帯域では概ね $3 \mathrm{~dB} / \mathrm{km}$ 程度 以下であり，1 km 進んでも信号は半分程度にしか減衰せず, 長距離にわたって信号を飛ばすことができる。無線通信で利 用が想定されるのはこのような低減衰の周波数帯であり，し 


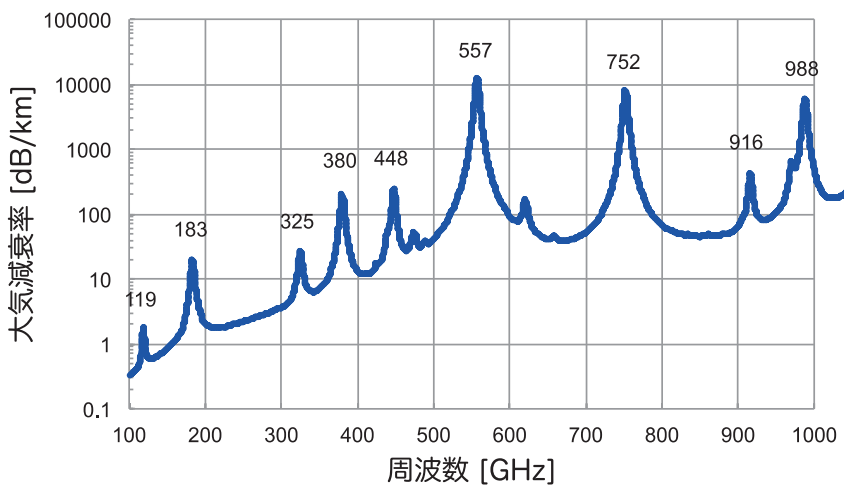

図1 $100-1,000 \mathrm{GHz}$ における大気による吸収 ${ }^{10)}$

ばしば「大気の空」とも呼ばれる。高周波になると所々に水 分子などの吸収バンドが存在するだけでなくベースラインも 上昇するため, 長距離の信号伝達は一般的に難しい。一方, 近距離を伝搬させる場合は状況が異なる。例えば， $1 \mathrm{~m}$ あた りの減衰は図 1 の縦軸を 1/1,000 にすると得られるため, 最 も減衰の大きい $557 \mathrm{GHz} や 752 \mathrm{GHz}$ のピーク頂点の位置で も減衰率は約 $10 \mathrm{~dB} / \mathrm{m}(=10,000 \mathrm{~dB} / \mathrm{km})$, つまり, $1 \mathrm{~m}$ で高々 1/10 程度に減衰するだけである。この程度であれば，検出器 の感度が良好であれば十分に利用可能である。このように， テラヘルツ波の利用では, 使用帯域の伝搬距離と大気の吸収 をまず考慮する必要がある。特に，センシング・イメージン グ応用を想定した場合, 伝搬距離はたいてい $1 \mathrm{~m}$ のオーダー 以下になるため, 減衰の大きい特定の周波数にさえ注意して おけば，過㮃に神経質になる必要はない。

次に，センシング・イメージングの利用に関連するテラへ ルツ波の性質を述べる。テラヘルツ波は，プラスチック，セ ラミックなどの多くのソフトマテリアルを透過するため，非 破壞・非接触でこれらの製品内部を透視できる(図2) ${ }^{11)}$ 。透 過しやすいかしにくいかは，主として，対象物が極性を有す るかどうかによる。極性が小さければ，テラヘルツ波の入射 により電気双極子モーメントが生じにくいため，吸収・再放 射が小さくなり透過性が高くなる。テラヘルツ波は，多くの ソフトマテリアルに対して高い透過性を有する電波領域の中 で最も短い波長領域に位置する。このため, 適度な解像度 ( $\mathrm{mm}$ からサブ $\mathrm{mm}$ 程度)のイメージング検査が可能である。

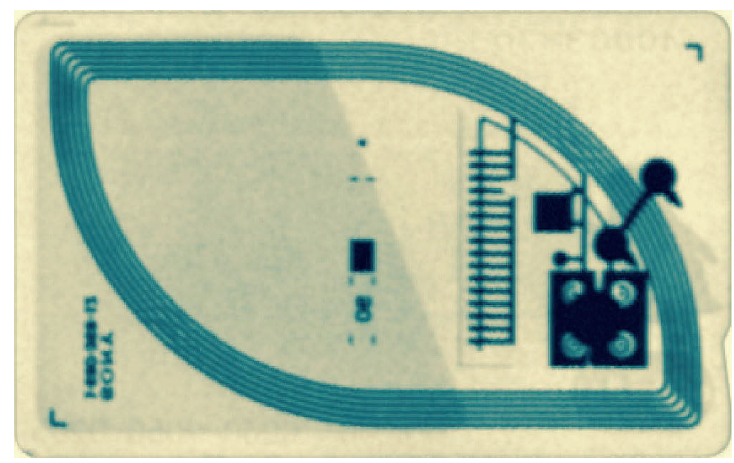

図 2 JR の SUICA カードのテラヘルツ透視画像 ${ }^{11)}$ 。使 用光源は後進波管(BWO) 連続波光源, 周波数 $600 \mathrm{GHz}$ ，空間分解能は約 $0.5 \mathrm{~mm}$ である。
一方，透過率は高周波ほど下がる。また，光源強度も周波数 が高いほど下がる傾向にあり，現行の連続波光源の典型的な 放射強度は, $100 \mathrm{GHz}$ で $100 \mathrm{~mW}, 300 \mathrm{GHz}$ で $1-10 \mathrm{~mW}$, $600 \mathrm{GHz}$ で $100 \mu \mathrm{W}$ 程度である ${ }^{12)}$ 。

これらの性質のため, 低周波領域は比較的厚みのあるサイ ズの大きなものを見るのに適し, 高周波領域は比較的薄いも のや小さいものを精細に見るのに適している。測定の空間分 解能 (つまり, 測定波長)を 1 ピクセルのサイズとした場合に 何ピクセルまで測定するのが適切かということとも関わって おり，典型的には $100-1,000$ ピクセル四方程度のサイズが ちょうど適したイメージ領域と考えられる。例えば, $300 \mathrm{GHz}$ （波長 $1 \mathrm{~mm}$ ）を用いた場合には, 測定対象物の典型的な大き さは $10 \mathrm{~cm}-1 \mathrm{~m}$ 四方くらいの大きさと想定できるだろう。

このように，テラヘルツ波の利用においては，測定対象物 の透過性と解像度の両方を考慮した最適周波数が存在するた め, 計測システムでどの周波数を用いるかは非常に重要なポ イントの一つである。典型的には, 透過性と空間分解能のバ ランスから，イメージングに適する周波数領域は概ね $100-$ $700 \mathrm{GHz}$ である。この周波数が B5G/6G の帯域とオーバー ラップすることは, 将来的に安価なデバイスを活用できると いう意味で非常に重要である。

\section{3. テラヘルツ波によるセンシング・イメージング}

上記の状況を踏まえて, 本章では, センシング・イメージ ングのツールとしてのテラヘルツ波の特長や応用可能性を振 り返った上で，今後予想される展開について述べる。テラへ ルツセンシング・イメージングの具体的な応用例はすでに多 数提案・報告されており膨大な量になるため, 参考文献とし て文献 13 を挙げておくが, その中でも直近のタイムスケー ルで最も重要な利用法は非破壊検査であろう。たとえば，ミ リ波に掛かる低周波領域では, タイルや建築材料などの比較 的大きな構造物が測定対象として有望である。一方，測定対 象の厚みが薄くて透過性が高く, かつ, 空間分解能が求めら れる場合には，やや高めの周波数を使ったほうが良い。図 3 に奨油・ソース等の液体を入れるプラスチック小袋のシール 部分のマイクロホールを测定した際の欠陷検知例 ${ }^{13)}$, 図 4 にコーティング下の錆の検知例 ${ }^{14)}$ を示す。

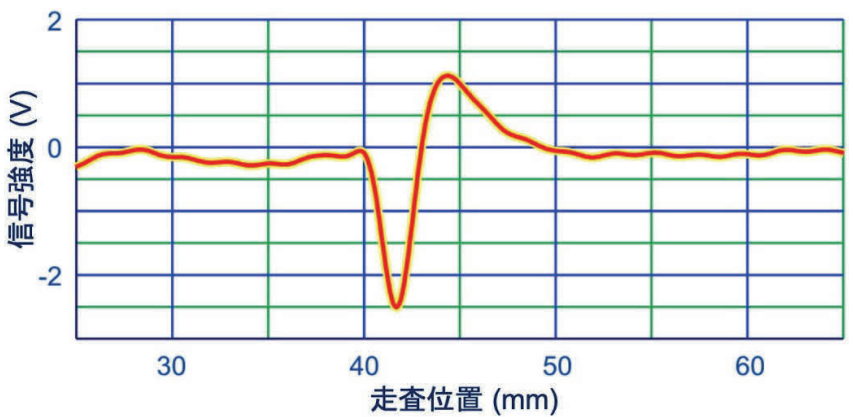

図 3 プラスチック液体小袋のシール部のマイクロホールの欠陥検 知結果。測定周波数は $600 \mathrm{GHz}$, 光源は BWO 連続波光源, 小袋の走查速度は $0.8 \mathrm{~m} / \mathrm{sec}$, 水の通ったマイクロホールの直 径は $100 \mu \mathrm{m}$ である ${ }^{14)}$ 。マイクロホール部では，水による吸 収と穴がレンズのような働きをすることから, 透過信号の強 度の減衰や変化が見られる。 
3 次元のイメージングの場合，位相情報をうまく活用する ことで奥行方向の空間分解能は波長よりも十分に小さい值ま で計測可能である。典型的には, 波長の数\%程度の分解能 を出すことが可能である。特に，テラヘルツ計測は非金属の コーティングに対する親和性が非常に高い。よく用いられる のは, テラヘルッ時間領域分光法 (THz-TDS) の超短パルス (パ ルス幅〜 1 ps) を用いた薄膜等の断層イメージングである。 図 4 は電力伝送用の鉄塔の防食塗装膜下の錆の検出例である ${ }^{15)}$ コーティング材料と金属酸化物の透過特性の違いや界面の存 在によって錆の部分がきれいに分離されているのがわかる。 このほか, 自動車の車体のコーティング厚み分布, 製薬分野 に打ける錠剂のコーティング厚みムラの検出など $10 \mu \mathrm{m}$

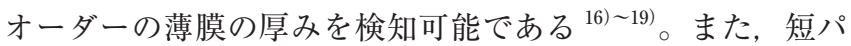
ルスの界面反射による断層イメージングだけでなく，テラへ ルッ光干渉断層イメージング(THz-OCT) を用いたイメージ ングでも $\mu \mathrm{m}$ オーダーの優れた断層イメージングが可能であ る ${ }^{20)}$ 。また，奥行き方向のイメージングについては，周波 数変調連続波レーダー $(\mathrm{FMCW})$ 方式や合成開ロレーダー

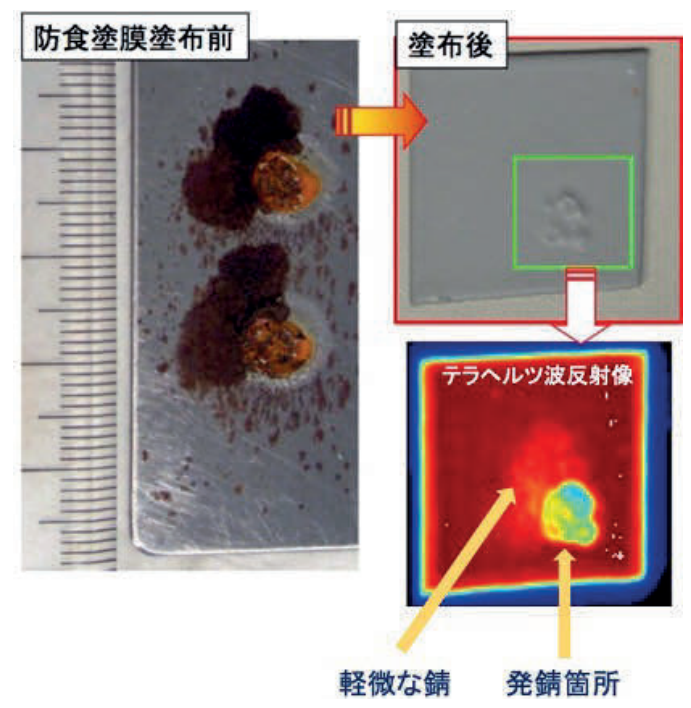

図 4 電力伝送用の鉄塔の防食塗装膜下の錆の検出 ${ }^{15)}$
$(\mathrm{SAR})$ の活用もなされている ${ }^{21), 22)}$ 。

\section{4. プラスチック材料のテラヘルツ分光}

テラヘルツ帯は分子間相互作用や生体分子などの大きな分 子の骨格振動の振動周波数に相当するため, 特に $1 \mathrm{THz}$ を超 える帯域のテラヘルツ分光によって赤外分光とは異なる緩や かな相互作用のセンシングが可能である。これらの振動は, 分子のサイズが大きいために計算で導くことは容易ではない が，物質ごとに異なるスペクトルの特徴を現象論的に活用し た物質種の同定・弁別も可能である。また，吸収スペクトル の計算も進みつつあり, 吸収ピークの同定, 特に, 水素結合 による吸収構造の同定も行われている ${ }^{23), 24)}$ 。また，テラへ ルツ波は極性が高い液体である水にはよく吸収され，水分を 含む物質のセンシングには制限がある一方で，ごく微量の水 のセンシングに高い感度を有する。図 5 はプラスチックフィ ルムに吸着したわずかな水分が検知可能であることを示して いる ${ }^{25)}$ 。なお, 吸収は水が水になると劇的に減少するため, その特性を活用したセンシングも可能である ${ }^{26), 27) 。 ~}$

\section{5. テラヘルツシステムのコンポーネント}

すでに述べたように，B5G/6G の流れが進むにつれて，半 導体を用いた小さく安価な光源や検出器などの主要コンポー ネントが実際の計測に用いられるようになると期待される。 しかし, 実際のシステムは光源と検出器だけで構成されるわ けではない。図 6 は我々がプロトタイプ機の研究開発を進め ている $300 \mathrm{GHz}$ 帯ウォークスルーボティスキャナーの実際 の光学系の写真である。このシステムでは, FMCW レーダー 方式を用いた 3 次元イメージングを行うが，それを実現する ために, レンズ, ミラー, ビームスプリッターといった光学 コンポーネントを組み合わせて使用している。この時に注意 すべき点は迷光の存在である。このシステムでは, 光源強度 とへテロダイン検出の比 (実効的な信号対雑音比 $(\mathrm{S} / \mathrm{N}$ 比)に 相当) が $110 \mathrm{~dB}$ (11 桁) に及ぶため, 光源からの光が想定と は異なる方向から入射すると, それが測定精度を劣化させて しまう可能性がある。そこで重要となるのがシステム内部の
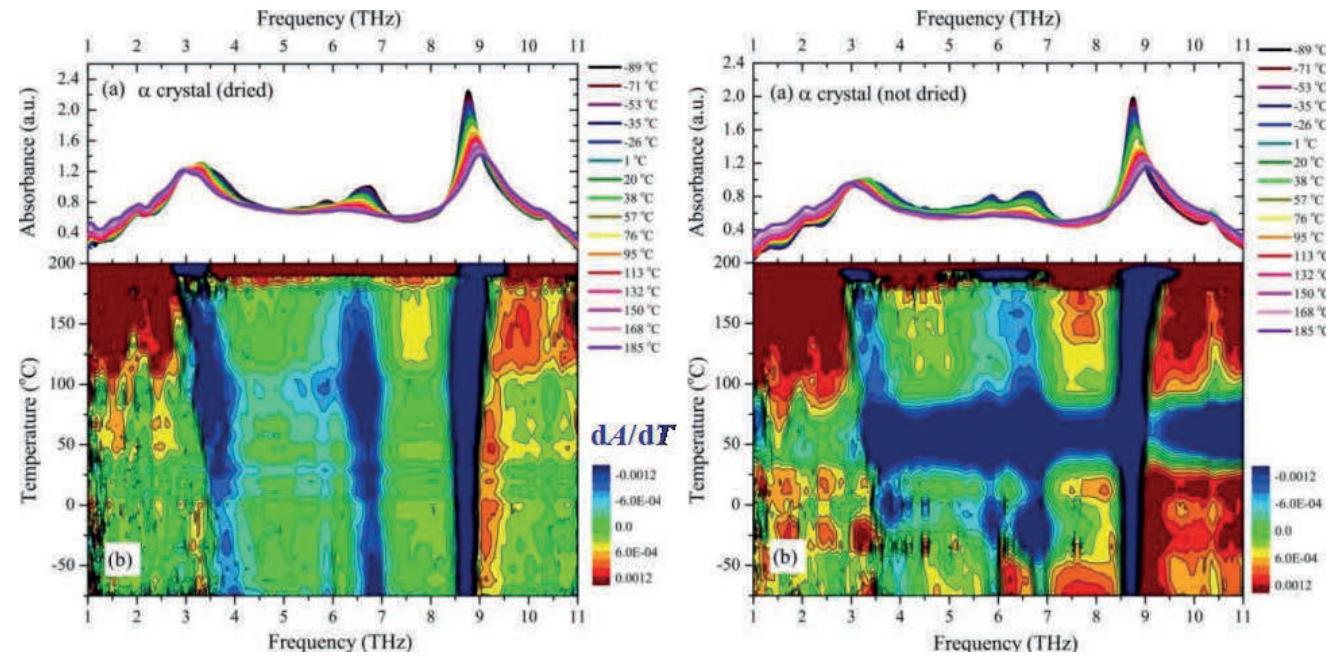

図 5 乾燥なし(左) と乾燥済(右)のナイロンフィルムの温度ごとの吸収 (上段) と温度変化率 (下段)。乾燥 なしのサンプルで $50-100{ }^{\circ} \mathrm{C}$ の温度域でフィルム表面に吸着した水による吸収変化が見られる ${ }^{25)}$ 。 


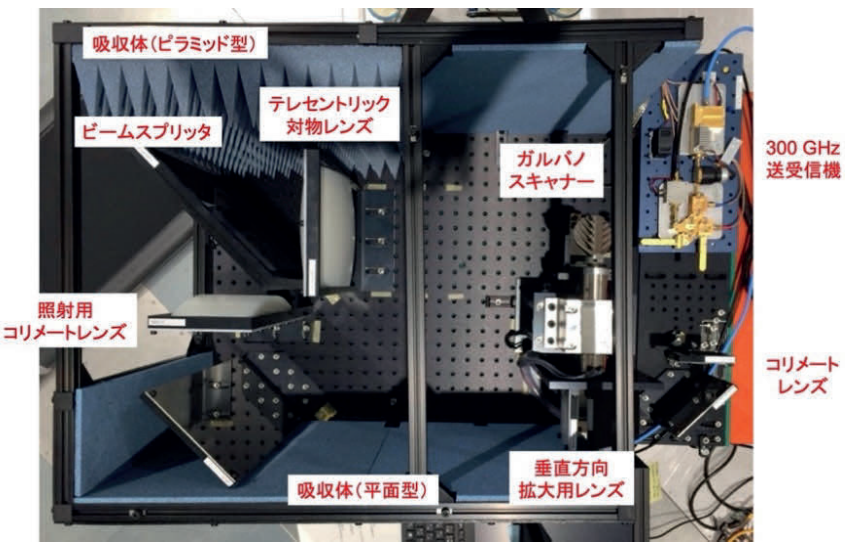

図 6 開発中のテラヘルツウォークスルーボディスキャナーの光学 系。送受信機, レンズ, ミラー, ビームスプリッターといっ た光学コンポーネントに加えて, 不要な反射を防ぐための吸 収体の活用も必須である。

壁面に設置している吸収体である。

このような吸収体は，壁面に当たった迷光をできるだけ反 射・散乱しないことが求められる。最も一般的に用いられる

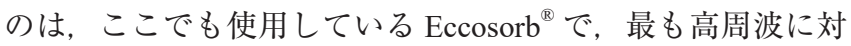
応したものでも反射率はおおよそ $-30 \mathrm{~dB}$ 程度(正反射成分 の実測值)であり，上記の $\mathrm{S} / \mathrm{N}$ 比からわかるように，より低 反射率の吸収体への要望は依然として強い。また, レンズな どの光学材料においても, 無反射コーティングが施されるこ とが本来は望ましい。微細加工技術を用いて表面付近の反射 を低減させる技術もあるが, 製作コストまで勘案すると,コー ティングが活躍できる場はまだまだあると思われる。ただし 単純なコーティングの場合には波長程度の厚みが必要となる ため, コストパフォーマンスの高い無反射コーティングを実 現するには, 可視光領域のような薄い無反射コーティングと は異なる発想も必要になると思われる。

\section{6. おわりに}

以上，本稿では，テラヘルツセンシング・イメージングの 観点から, 近未来の $\mathrm{B} 5 \mathrm{G} / 6 \mathrm{G}$ の動向を見据えて, 表面技術に 多少なりとも関わると考えられる応用例を中心に概観した。 一方，筆者は無線通信の専門家ではなく，本稿では B $5 \mathrm{G} / 6 \mathrm{G}$ の本丸である無線通信用のデバイスに求められる誘電体薄膜 については触れられなかった。しかし，これが極めて重要で あることは言うまでもない。実際，高周波になればなるほど, ほんのわずかの誘電体損失や設計值のずれが伝搬信号の著し い減衰・損失を生み, 通信の不具合を発生させる要因となる と考えられる。高周波領域において実用的なシステムで要求 される精度は, 恐らくはこれまでとは比較にならない高精度 のものであり, 周波数の上昇に伴って近い将来に大きな壁と なって立ちはだかるだろう。その意味で, 良質な誘電体材料 の開発, そして, その適切な評価は極めて重要である。その 評価には，上記のようなセンシング・イメージング技術の高 度化も不可欠であり, デバイスの活用のみならず, 通信とセ ンシングが両輪となって相互に技術を高めていくことが今後 求められると考えている。

\section{文献}

1) NTT docomoホワイトペーパー「5Gの高度化と6G(3.0版)」(2021).

2 ) SoftbankニュースWeb site, $5 \mathrm{G}$ の先の未来へ, Beyond 5G/6Gに向け たテラヘルツ波への挑戦(2020). https://www.softbank.jp/sbnews/ entry/20200618_02

3 ）総務省 Beyond 5G推進戦略筤談会Web site, https://www.soumu. go.jp/main_sosiki/kenkyu/Beyond-5G/index.html

4 ) NEDOポスト $5 \mathrm{G}$ 情報通信システム基盤強化研究開発事業Web site, https://www.nedo.go.jp/activities/ZZJP_100172.html

5 ）情報通信研究機構 Beyond 5G/6Gホワイトペーパー(2021).

6 ）大谷知行, 寶迫 巌; 科学技術に関する調查プロジェクト2016報 告書 - 冷戦後の科学技術政策の変容, p. 121 (国会図書館, 2017).

7 ) 経済産業省 通商白書2019 (2019).

8 ) T. Woodward ; $100 \mathrm{~Gb} / \mathrm{s}$ RF Backbone (100G), web site, http://www. darpa.mil/program/100-gb-s-rf-backbone

$9)$ S. Lee, R. Dong, T. Yoshida, S. Amakawa, S. Hara, A. Kasamatsu, J. Sato, M. Fujishima ; IEEE International Solid-State Circuits Conference (ISSCC) (2019). https://www.hiroshima-u.ac.jp/ news $/ 49768$

10）情報通信研究機構，テラヘルツ波大気減衰率提供サービス, https://smiles-p6.nict.go.jp/thz/jp/decay.html

11) A. Dobroiu, M. Yamashita, Y. N. Ohshima, Y. Morita, C. Otani, K. Kawase ; Applied Optics, 43, 5634 (2004).

12) K. Sengupta, T. Nagatsuma, D. M. Mittleman ; Nature Electronics, 1 , $622(2018)$

13）深澤亮一 ; 分析・センシングのためのテラヘルツ波技術(日刊工 業新聞社, 2013).

14) Y. Morita, A. Dobroiu, C. Otani, K. Kawase ; J. Food Protection, 68, 833 (2005)

15）布施則一, 高橋招大, 福地哲生, 水野麻弥, 福永 香; 電力中央研 究所報告, 研究報告:H11002 (2011).

16) T. Yasui, T. Yasuda, K. Sawanaka, T. Araki ; Appl. Opt., 44, 6849 (2005).

17) K. Su, Y.-C. Shen, J. A. Zeitler ; IEEE Trans. TeraHz. Sci. Tech., 4, 432 (2014)

18) J. A. Zeitler, P. F. Taday, D. A. Newnham, M. Pepper, K. C. Gordon, T. Rades ; J. Pharm. Pharmacol., 59, 209 (2007).

19) Y.-C. Shen, P. F. Taday ; IEEE J. Sel. Top. Quantum Electron., 14, 407 (2008)

20) T. Nagatsuma, H. Nishii, T. Ikeo ; Photon. Res., 2, B64 (2014).

21) K. B. Cooper, R. J. Thomas, N.Llombart, B. Thomas, G. Chattopadhyay, P. H. Siegel ; IEEE Trans. TeraHz. Sci. Tech., 1, 169 (2011)

22) S. Palm, R. Sommer, A. Hommes, N. Pohl, U. Stilla ; Int'l Arch. Photogram. Rem. Sens. Spat. Info. Sci., XLI-B1, 81 (2016).

23) S. Yamamoto, Y. Mirisawa, H. Sato, H. Hoshina, Y. Ozaki ; J. Phys. Chem. B, 117, 2180 (2013)

24) H. Hoshina, S. Ishii, S. Yamamoto, Y. Morisawa, H. Sato, T. Uchiyama, Y. Ozaki, C. Otani ; IEEE Trans. THz Sci. Tech., 3, 248 (2013).

25) H. Suzuki, S. Ishii, C. Otani, H. Hoshina ; Euro. Polymer J., 67, 284 (2015).

26）水野麻弥, 栗原庸輔, 大谷知行, 進藤賢治, 小川雄一, 松木英敏, 川 瀬晃道; 電気学会論文誌E, 125-E, 229 (2005).

27) H. Hoshina, A. Hayashi, N. Miyoshi, F. Miyamaru, C. Otani ; Appl. Phys. Lett., 94, 123901 (2009). 